\title{
FLOOD HAZARD MAPPING USING GIS SPATIAL ANALYSIS FUNCTIONS IN BALEENDAH, BANDUNG, WEST JAVA
}

\author{
Redho Surya Perdana ${ }^{1}$, Mai Cong Nhut ${ }^{2}$, Adam Irwansyah Fauzi ${ }^{1}$ and Rahma Hanifa ${ }^{2}$ \\ ${ }^{1}$ Geomatics Engineering, Sumatera Institute of Technology \\ ${ }^{2}$ Geodesy and Geomatics Engineering, Bandung Institute of Technology, Indonesia \\ Email: redhosurya17@gmail.com
}

\begin{abstract}
Flooding is the most devastating hydro-meteorological hazard in Baleendah. Therefore, communities in Baleendah needs more attention because they suffer the impacts every year. This paper focused on mapping flood hazard in the 1-km2 area in Baleendah. The study used spatial analysis functions in ArGIS. Also, an on-site survey was conducted to know the height of inundation by floods within the study area. The resulting flood hazard map shows that all communities are exposed to flood hazard with the total number of 5349 houses inundated by floods. The degree of inundation is divided into three (03) levels, low (0-0.5 m), moderate $(0.5-1.5 \mathrm{~m})$, and high (above $1.5 \mathrm{~m})$. Positive attitude towards early actions and early warning systems, collaboration among disaster relief institutions and local government are recommended for reduction of flooding disaster risk.
\end{abstract}

Keywords: Flood hazard mapping, Baleenda, GIS

\section{A. INTRODUCTION}

Flooding is one of the most devastating hazards worldwide, which affects people's lives, socio-economic and ecological systems (Alexander et al., 2011). Flood hazards are the most common and destructive of all disasters and are a constant threat to life and property. Each year, flood disasters result in tremendous losses and social disruption worldwide, with significant consequences including: a) human and animal life losses, b) destructions of infrastructures, communication networks, and agricultural/livestock buildings, c) loss of crops and soils, d) transport of sediment loads and pollutants (Downton and Pielke, 2001; Golian et al., 2010). Worldwide floods, especially during the last decades, record significant high rates both in absolute number of events, and in terms of financial losses. Specifically, it is estimated that floods cause about $40 \%$ of the damages caused by all natural disasters (Ologunorisa and Abawua, 2005; Munich Re, 2016).

Researchers have different views on the conceptualization of flooding based on the sources, impacts, extent or a combination of different factors. Schanze (2006), Nyarko (2000), and Merz et al. (2007) conceptualized flooding as inundation of an area by unexpected rise of water by either dam failure or extreme rainfall duration and intensity in which life and properties in the affected area are under risk. An event becomes a disaster when there is a serious disruption to the functioning of a community involving widespread human, material, economic or 
environmental losses and impacts, which exceed the ability of the affected community to cope using its own resources (UNI-SDRR，2004; UN-ISDR， 2009). European Commission (EC, 2007), perceived flood risk as the combination of the probability of a flood event and of the potential adverse consequences for human health, the environment, cultural heritage and economic activity associated with a flood event. It is important to recognize that flood risks are human or societal concern rather than being an inherent characteristic of the natural system.

Many countries especially in Southeast Asia and Africa face a severe increase in flood risk (Di Baldassarre et al., 2010a; Winsemius et al., 2016). The different types of flooding are: river floods, flash floods, coastal flooding, urban floods, and sewer flooding (Kourgialas and Karatzas, 2016).

Flood risk maps are generated using multi-parametric approaches that combine physical (hazard) and socio-economic (vulnerability) factors. Nevertheless, existing global flood risk projections fail to accurate predict the dynamics of socioeconomic development or/and climate change (Ward et al., 2015; Winsemius et al., 2016). The knowledge of flood hazard is also essential to adapt any strategy for minimizing the flood risk, which in turn can reduce the losses of human life and damages in urban and rural sectors (Pappenberger et al., 2013; Sampson et al., 2015). Flood hazards can be defined as threatening events, or the probability of occurrence of a potentially damaging phenomenon within a given time period and area (Di Baldassarre et al., 2010b). However, in recent years, flood hazard maps are still lacking in many countries. This is mainly due the limited availability of adequate data for flood hazard studies such as hydrologic observations, historical flood events, and topographical surveys of channels/floodplains (Samela et al., 2017). All these data are rarer in ungauged river basins of many developing countries of Asia, Africa, or South America. Based on this, for producing large scale flood hazard maps, several researchers have addressed the prediction of flood hazard at ungauged sites by using regionalization methods, simplified hydrological routing schemes, methods based on geomorphology for generating relationships between flood and floodplain, and using high resolution satellite images for quantifying changes in surface water (Nardi et al., 2006; Dodov and Foufoula-Georgiou, 2006; Manfreda et al., 2011; Pekel et al., 2016; Samela et al., 2017).

Geospatial techniques such as Remote Sensing and Geographic Information System (GIS) have been useful tools for mapping floodplains and flood disaster 
risks in most parts of the world and the outputs proved efficient and useful in disaster management planning (USGS, 2011; Nyarko et al., 2015). Research works in different parts of the world have shown that integration of remote sensing data, flood hazard data, and data on socioecological indicators within GIS platforms, is an efficient approach to generate flood vulnerability and risk maps for a given area (Nyarko, 2002; Forkuo, 2012; Merz et al., 2007).

It is important to have hazard, vulnerability and risk maps at community to identify vulnerable elements to help save lives and properties. Therefore, the main objective of this work is to propose a methodology to create a flood risk map using GIS spatial analysis functions in Baleendah, Bandung, West Java, Indonesia.

\section{B. MATERIALS AND METHODS}

The study was conducted in Baleendah, Bandung, West Java, Indonesia. The study area extends between $6^{\circ} 59^{\prime} 18.8 ", \mathrm{~S}$ to $6^{\circ} 59^{\prime} 52^{\prime \prime} 7$ and $107^{\circ} 37^{\prime} 24.4^{\prime \prime}$ to $107^{\circ} 37^{\prime} 58.3^{\prime \prime}$. Baleendah is part of is part of the upstream Citarum watershed. The Citarum River Basin (DAS) is the largest watershed in West Java with an area of $6,614 \mathrm{~km}^{2}$ and a length of $300 \mathrm{~km}$ (Jasa Tirta II, 2002 in Hadisantosa, 2006). The Citarum watershed was inhabited by 8.5 million inhabitants (1999) held several important roles, among others (Wardhani, 2005):

- It is where the existence of three large reservoirs in West Java (Saguling, Cirata, and Jatiluhur) since 1962.

- Irrigate an agricultural irrigation network of 300,000 ha in the Pantura area of West Java

- Be a source of drinking water for the urban areas of Bandung, Cimahi, Cianjur, Purwakarta, Bekasi, Karawang, and Jakarta.

- Utilized for other purposes such as floating fish floating area, recreation, and sports facilities.

Baleendah is a flood subscription area in West Java. Since ten years ago, there have been frequent floods in this area. The study of Citarum River Basin (2011) characterized approximately 1,651.5 ha (39\%) of the Baleendah region potentially affected by floods each year (BBWS Citarum, 2011). 


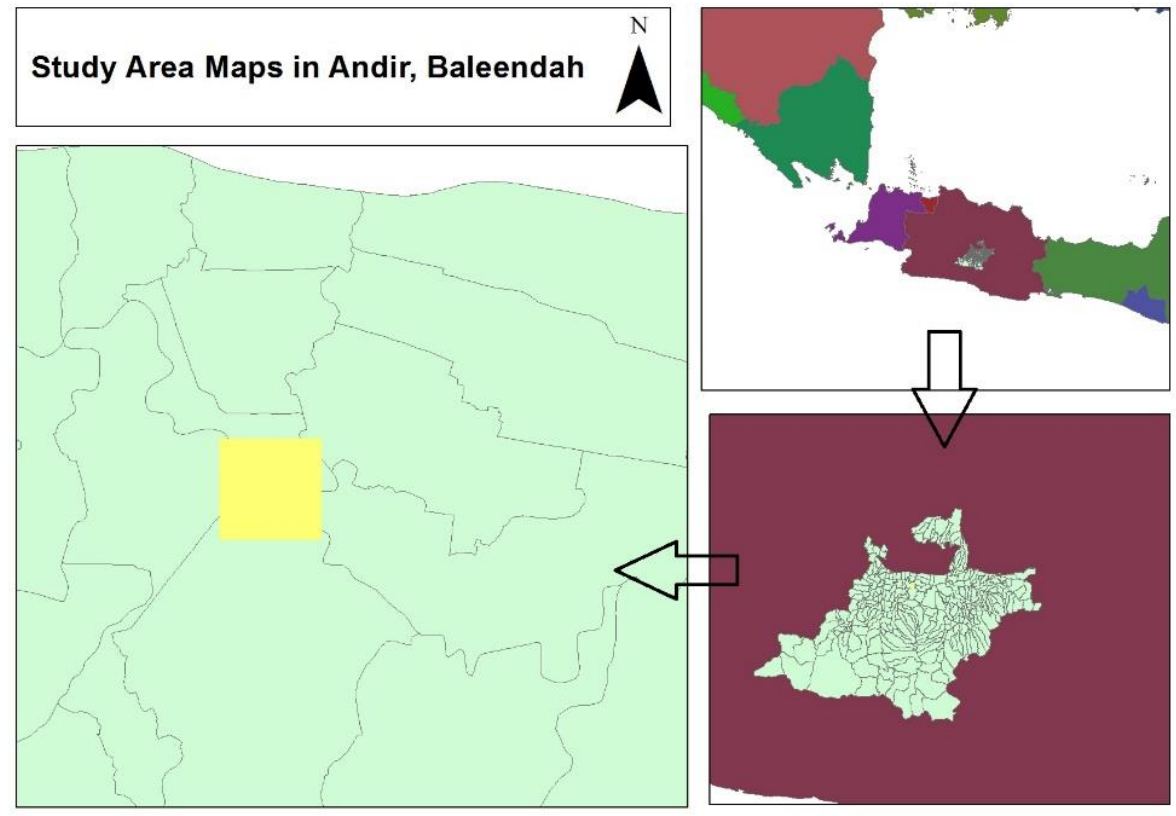

Figure 1. Maps of the study area in Andir, Baleendah

In this study, GIS-based spatial is applied to create a flood hazard map in Baleendah. The study determines the potential of inundation to know which houses might be inundated by floods. Also, community consultation is conducted to know the degree of inundation in the study area. Finally, the flood hazard map with different levels of inundation is created. To do so, the following procedure is applied.

- Firstly, a digitization process is performed to obtain spatial data such as river and housing data in the research area.

- Secondly, an on-site survey is conducted to know the height of inundation in the research area.
- Then, we perform spatial analysis functions in ArcGIS (Buffer and Intersect) to find out how many houses might be inundated by floods.

- Finally, the flood hazard map with different level of inundation is created. This category is based on survey data of flood height in the research area. The low category is based on the height of inundation from $0-0.5$ meter, the moderate category is based from the height of inundation from 0.5-1.5 meters, and the high category is based on a flood height above 1.5 meters. Then the data is processed into raster form and categorized from low to high. 


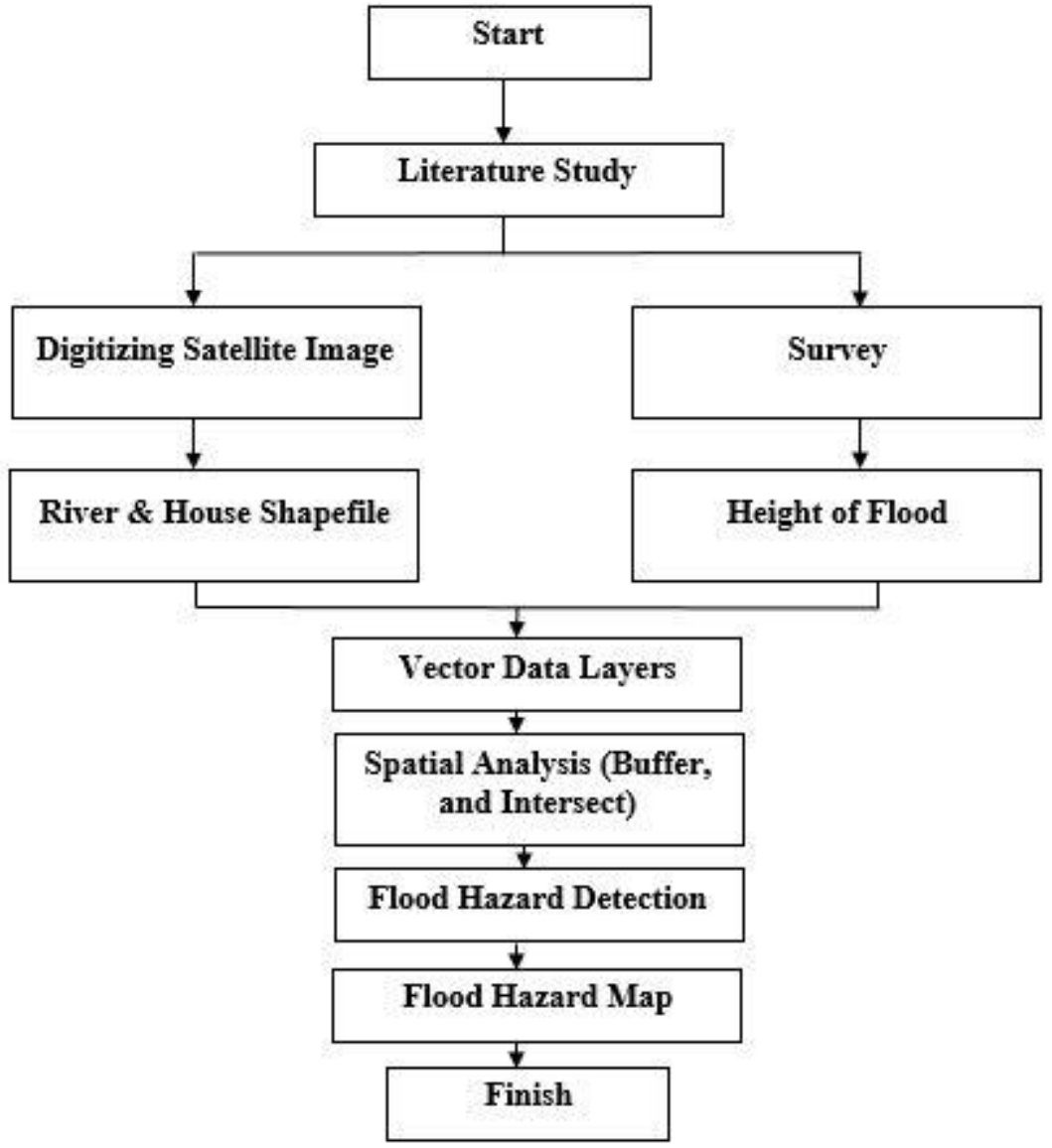

Figure 2. Methodology

\section{RESULTS AND DISCUSSION}

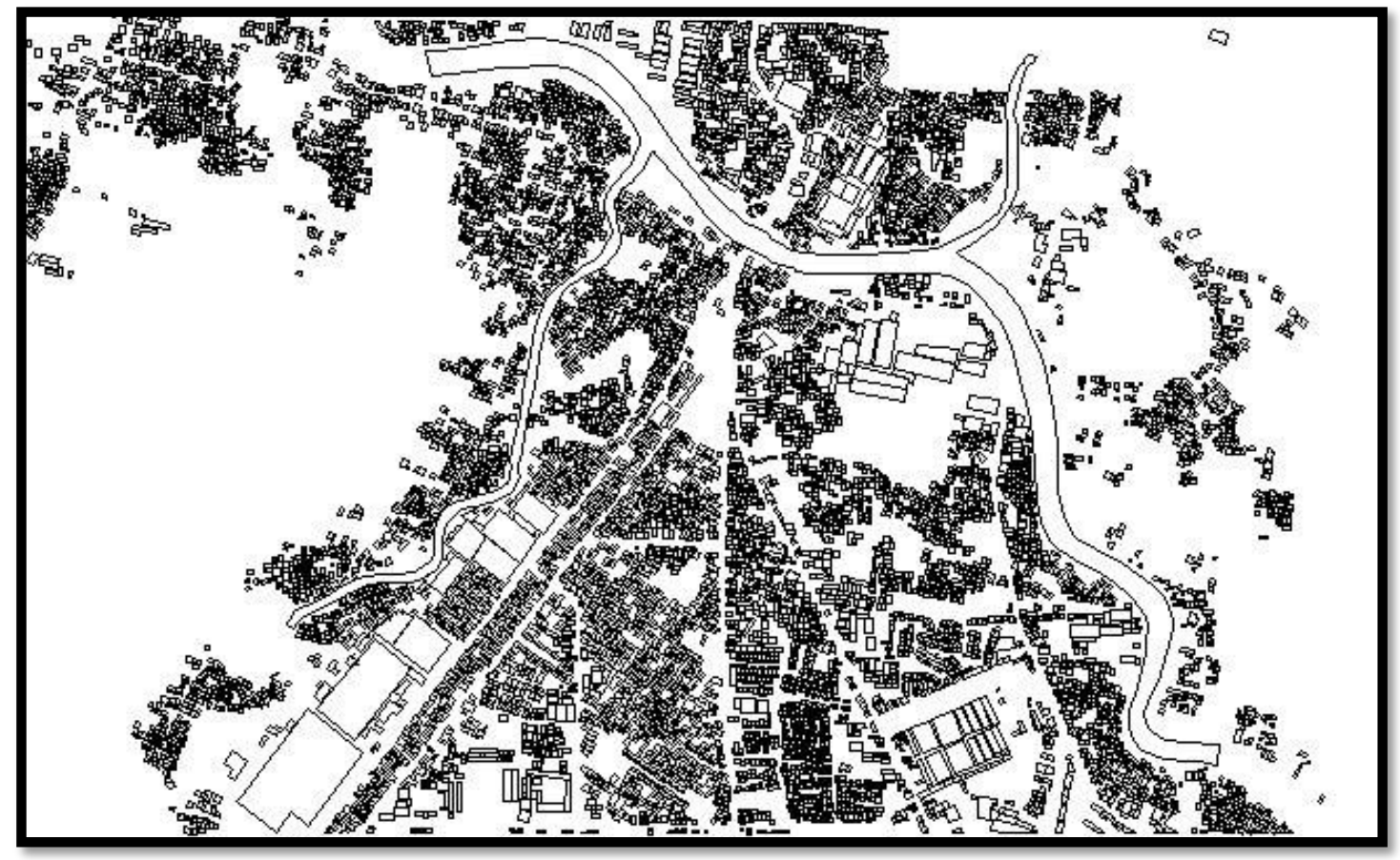

Figure 03. Spatial data of river and house distribution in the study area 


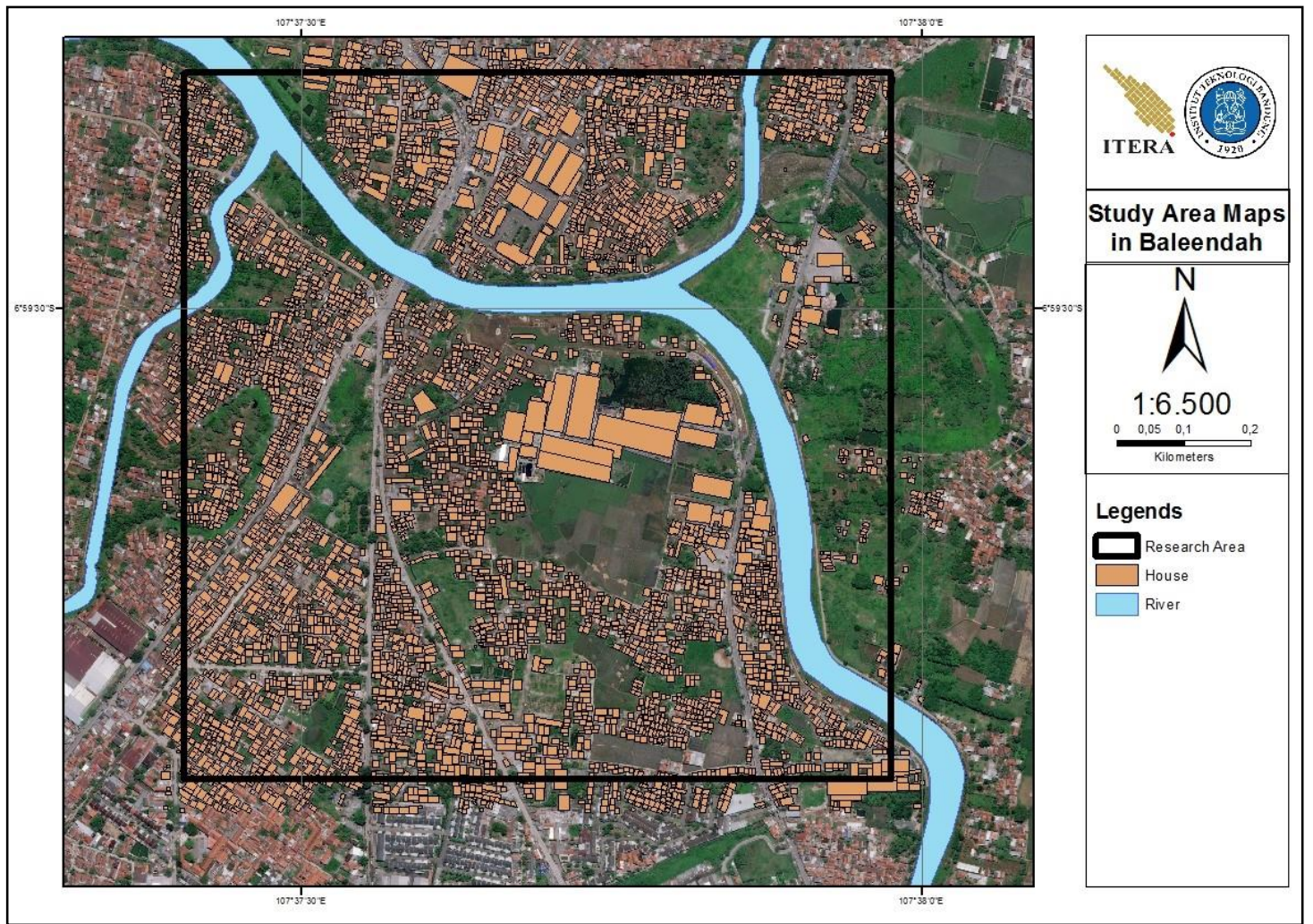

Figure 04. Baleendah Area

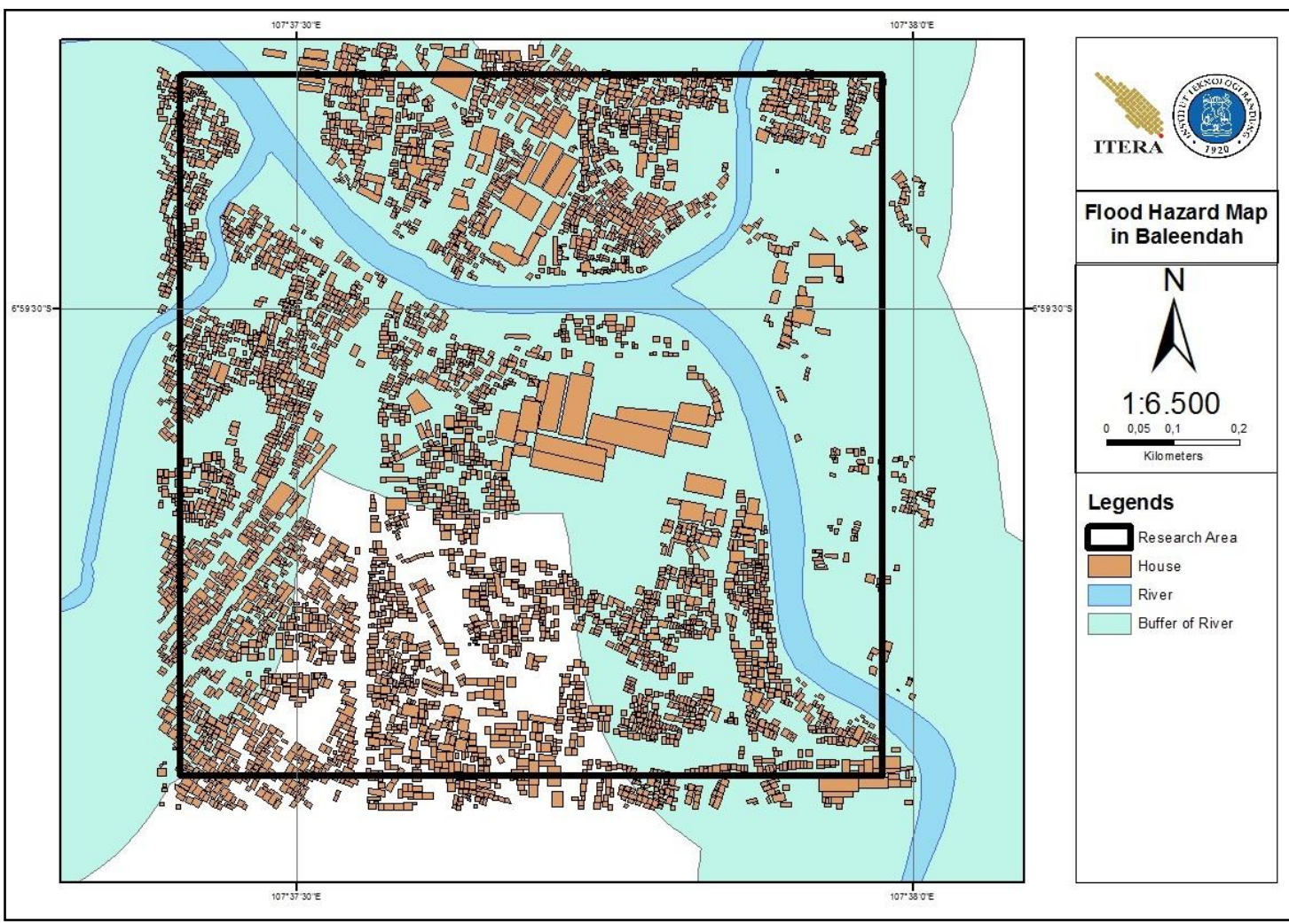

Figure 05. Result of Buffering River in Baleendah Area 


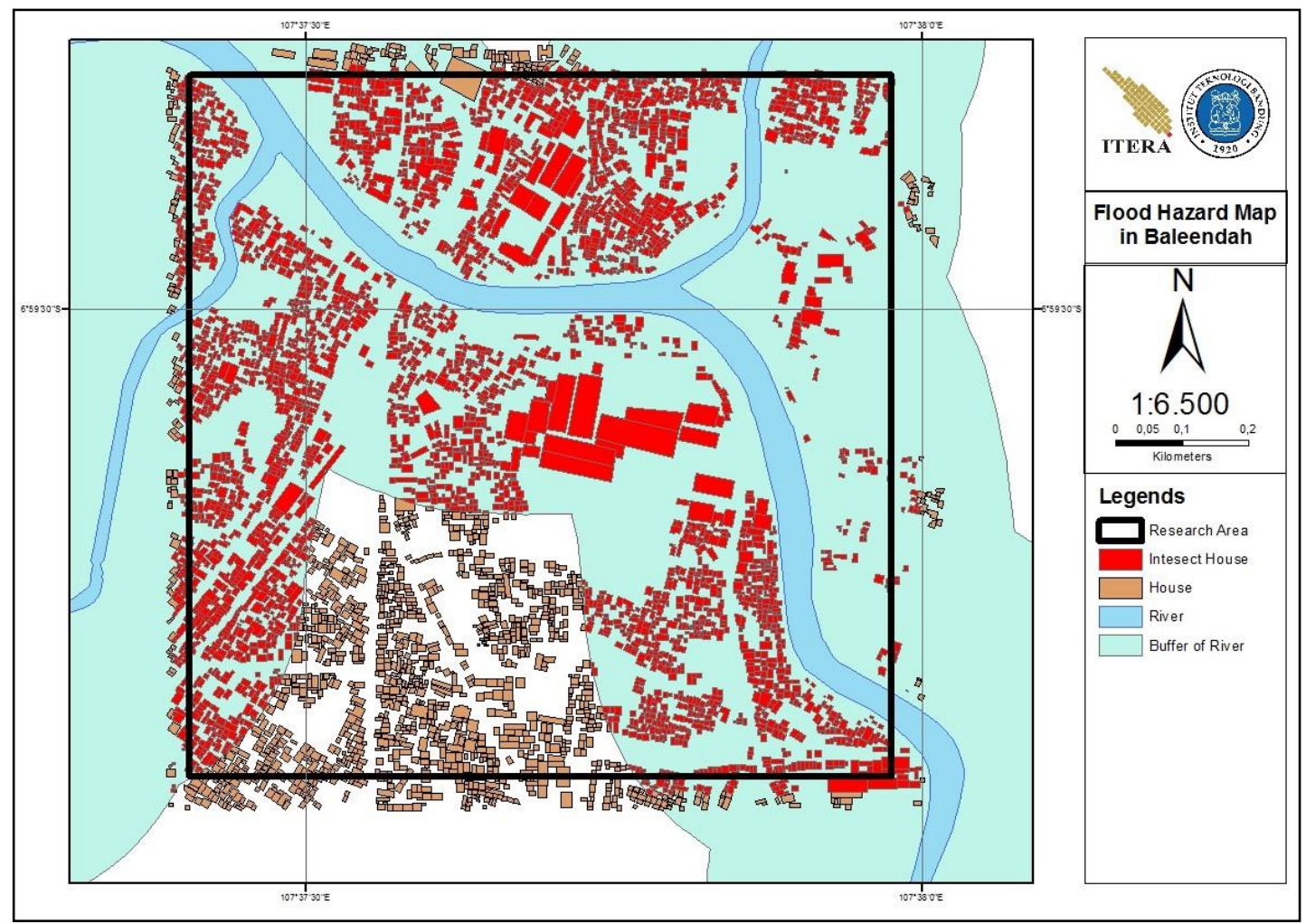

Figure 06. Result of Intersect from Buffer River and House

One way to create a flood hazard map is to do spatial analysis (buffer and intersect). To do that, we must have a river vector data to do spatial analysis. According to Indonesia's disaster risk book, the process for creating disaster risk maps requires a buffer spatial analysis process. This process is done by buffering by 300 meters in the river in the research area.
After that, we conducted a spatial analysis process using intersect to get the number of houses that have flood impact in the research area. From the data processed, then obtained the result that there are 5349 houses that have flood impact in the research area. This illustrates that in the study area almost all houses have flood impacts coming from the citarum river. 


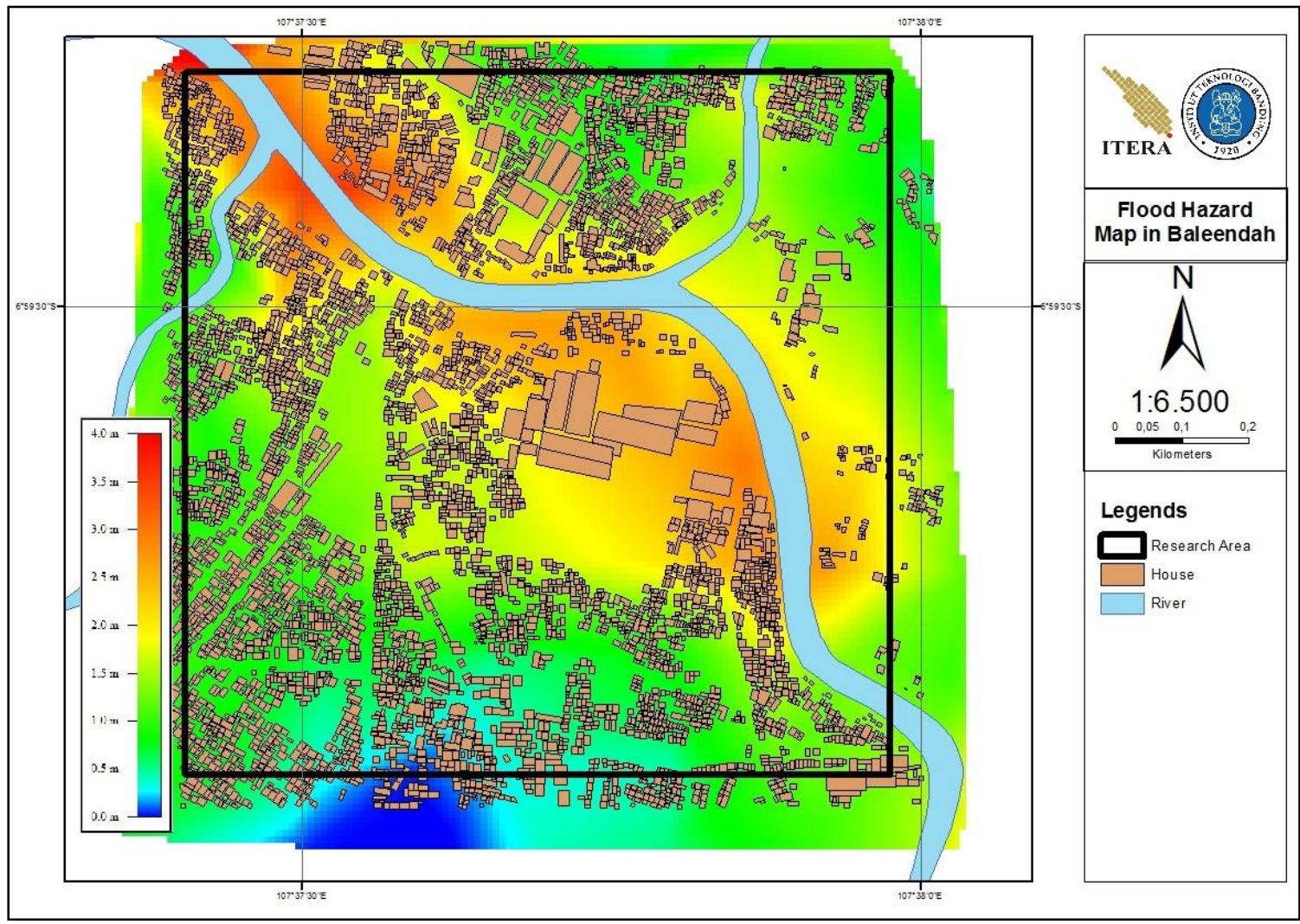

Figure 07. Risk Maps of Flooding in Andir, Baleendah

To strengthen the analysis in creating flood hazard maps, we surveyed the entire study area to obtain overall flood heights by creating sample points and making simple models with a view to illustrating and creating flood hazard categories in the study area. Based on the survey data we got across the study area, we analyzed that overall houses in the study area had an impact on flooding. However, the height of the floods in different regions. We analyze that the danger of flooding will be even greater if the house gets closer to the river.

\section{CONCLUSIONS}

Based on the data and results of part 4, the following conclusions are obtained:
1. According to Indonesia's disaster risk books, in theory the impact of floods will extend along 300 meters from the river. By following this theory and the results of research, it can be concluded that the house that impacted flooding in the research area is 5349 homes.

2. However, after we conducted a field survey, all houses were affected by flooding in all research areas. But the impact of the floods has variations in flood heights. These altitudes range from 0.1 - 4 meters.

3. Based on survey data and filling questionnaires, Floods in the study area came due to high rainfall and 
water delivery from other regions such as Majalaya, Dayeuhkolot, Dago, and other areas.

4. Based on the results of the questionnaire, Baleendah area is a basin area that makes this area a place

\section{E. REFERENCES}

Alexander, M., Faulkner, H., Viavattene, C. and Priest, S. (2011). A GIS-based Flood Risk Assessment Tool; Supporting Flood Incident Management at the local scale. Proof of concept report to the Flood Risk Management Research Consortium (FRMRC2).

BBWS Citarum Kementerian PU. (2011) Peta Informasi Citarum. Roadmap Coordination and Management Unit. Penanganan Banjir Sungai Citarum Hulu.

Di Baldassarre, G., Schumann, G., Bates, P., Freer, J., and Beven, K. (2010b). Floodplain mapping: a critical discussion on deterministic and probabilistic approaches. Hydrol. Sci. J. 55 (3), 364-376.

Diakakis, M., Mavroulis, S., and Deligiannakis, G. (2012). Floods in Greece, a statistical and spatial approach. Nat. Hazards 62, 485-500.

Dodov, B.A. and Foufoula-Georgiou, E. (2006). Floodplain morphometry extraction from a high-resolution digital elevation model: a simple algorithm for regional analysis studies. IEEE Geosci. Remote Sens. Lett. 3 (3), 410-413.

Downton, M.W. and Pielke, R. (2001). Discretion without accountability: politics, flood damage, and climate. Nat. Hazard. Rev. 2 (4), 157-166.

European Commission (EC) "Directive 2007/60/EC of the European for gathering rain water from other regions.

5. As a disaster mitigation measure, the government is planning the creation of a water bank to hold water when the floods are coming.

Parliament and of the Council of 23 October, 2007" on the assessment and management of flood risks, Official Journal of the European Union, L288/27-34: 2014.

Forkuo, E. K., Asare, and Mensa, Y. (2012). River Inundation and Hazard Mapping - a Case Study of Susan River-Kumasi. Proceedings of Global Geospatial Conference, 14-17 May 2012,

Quebec City, Canada. Nyarko, B.K., Diekkrüger, B., Van De Giesen, N. C., and Vlek, P.L.G. (2015). Floodplain wetland mapping in the White Volta River Basin of Ghana. GIScience and Remote Sensing. DOI: 10.1080/15481603.2015.1026555.

Georgakakos, K.P. (2006). Analytical results for operational flash flood guidance. J. Hydrol. 317, 81-103.

Kourgialas, N.N., Koubouris, G.C., Karatzas, G.P., and Metzidakis, I. (2016). Assessing water erosion in Mediterranean tree crops using geoinformatic techniques and field measurements; the effect of climate change. Nat. Hazards. Doi: http://dx.doi.org/10.1007/s11069016-2354-5.

Management Unit. (2011) Penanganan Banjir Sungai Citarum Hulu.

Manfreda, S., Di Leo, M., and Sole, A. (2011). Detection of flood prone areas using digital elevation models. J. Hydrol. Eng. 16 (10), 781-790. 
Merz, B., Thieken, A.H., and Gocht, M. (2007). Flood Risk Mapping at the local Scale: Concepts and challenges. ResearchGate, Postdam, Germany: 2007, available at; http://www.researchgate.net/publicat ion/226038430.

Munich R. (2016). Natural catastrophes 2015. Annual figures. Munich Re NatCat Service. Available online:http://www.munichre.com/site /corporate/get/params_E1254966961 _Dattachment/1130647/Munich-ReOverview-Naturalcatastrophes2015.pdf

Nardi, F., Vivoni, E. R., and Grimaldi, S. (2006). Investigating a floodplain scaling relation using a hydrogeomorphic delineation method. Water Resources Research, 42(9). 10.1029/2005WR004155.

Nyarko, B. K. (2000). Flood Risk Zoning of Ghana: Accra Experience. International Archives of Photogrammetry and Remote Sensing,Vol. XXXIII, Part B7. Amsterdam, The Netherlands.

Nyarko, B.K. (2002). Application of a rational model in GIS for flood risk assessment in Accra. Journal of Spatial Hydrology, 1-12.

Ologunorisa, T.E. and Abawua, M.J. (2005). Flood risk assessment: a review. J. Appl. Sci. Environ. Manag. 9 (1), 57-63.

Pekel, J.F., Cottam, A., Gorelick, N., and Belward, A.S. (2016). Highresolution mapping of global surface water and its long-term changes. Nature 540, 418-422.

Samela, C., Troy, T.J., and Manfreda, S. (2017). Geomorphic classifiers for flood-prone areas delineation for data-scarce environments. $A d v$. Water Resour. 102, 13-28.
Schanze, J. (2006). Flood risk management a basic framework. Chapter 1 of Flood Risk Management - hazards, vulnerability and mitigation measures, NATO Science Series, IV Earth and Environmental Sciences, Vol. 67, Springer, Dordrecht, The Netherlands.

UN-ISDR. (2009). Disaster Risk Reduction, Risk and Poverty in a Changing Climate: Invest today for a safer tomorrow. Global Assessment Report, assessment for disasters in urban areas, Fernerkundung and Naturkatastrophen.

UNI-SDRR (2004). Living with Risk, a Global Review of Disaster Reduction Initiatives. United Nations Office for Disaster Risk Reduction (UNISDR).

USGS (2011). Landsat Missions: Panchromatic Image Sharpening of Landsat 7 ETM+. 2011, available athttp://landsat.usgs.gov/panchromati cimagesharpening.php, last assessed 20/5/2015.

Ward, P.J., Jongman, B., Salamon, P., Simpson, A., Bates, P., Groeve, T.D., Muis, S., Perez, E.C. de, Rudari, R., Trigg, M. A., and Winsemius, H.C. (2015). Usefulness and limitations of global flood risk models. Nat. Clim. Chang. 5 (8), 712-715.

Ward, P.J., Jongman, B., Salamon, P., Winsemius, H.C., Aerts, J.C. J.H., Beek, L. P. H. van, Bierkens, M.F. P., Arno Bouwman, Kwadijk, J. C. J., Ligtvoet, W., Lucas, and Vuuren P.L., D.P. van (2016). Global drivers of future river flood risk. Nat. Clim. Chang. 6, 381-385.

Wardhani, E. (2005). Analisa Deposisi Logam Berat Krom Dari Resuspensi Sedimen Sungai Citarum Hulu Dalam Skala Laboratorium. Tesis S-2. Program Studi Teknik Pengelolaan Lingkungan ITB. Bandung. 